fashion which swept through a girls' school of taking thyroid for the purpose of securing lithe figures, a fashion which had serious results in several instances. There is a wide gap between maruanha and thyroid and a still wider one between the former and aspirin. "I may surprise some," said Dr. Kennedy, "if I refer to aspirin as a drug which gives rise to habit, and without being dogmatic I would merely give my opinion that it does". Another form of addiction, he said, was provided by certain medicated wines. Many people delude themselves with the idea that when a wine was 'medicated', it was somehow free from the stigma of what is picturesquely called the 'demon drink'. But there is no excuse for maruanha and no quarrel with the penalty which may be imposed in the State of New Jersey upon traffickers in this woeful drug, namely, thirty years imprisonment and a fine of ten thousand dollars.

\section{Twenty-five Years of Transcontinental Telephony}

Ir is recalled in the Laboratories Record of the Bell Telephone System that on January 25, 1915, just twenty-five years ago, the first transcontinental telephone call was made across America and the east and west were united. President Woodrow Wilson talked from the White House across the country testifying to the nation's pride "that this vital cord should have been stretched across America as a sample of our energy and enterprise". The inventor of the telephone, Alexander Graham Bell, in New York, repeated across the continent to San Francisco the first words ever heard over a telephone, namely, his call to his assistant, "Mr. Watson, come here, I want you," to the same T. A. Watson who had heard them in the garret workshop in Boston in 1876. That ceremony ushered in transcontinental service twenty-five years ago. At that time it cost 20.70 dollars to call San Francisco from New York. Now it costs 6.50 dollars for a station to station call and only 4.25 dollars after seven in the evening and all day on Sunday. In 1915 it took about half an hour, on the average, to make a connexion; now most calls are put through without 'hanging up'. The Bell System concludes by saying: "These are measures of progress in the never-ending effort of the Bell System to give faster, clearer, more useful and courteous service to the people of the United States".

\section{Development of the Battery Vehicle}

IN an article contributed to the Electrical Review of February 16, J. H. Cansdale states that during the last six years the number of battery vehicles has been rapidly increasing, and war-time conditions will most probably create a very much greater demand for them. In 1933, the number of battery vehicles registered in Great Britain and Northern Ireland was about 1,400, and it is estimated that the number at the beginning of this present year was about 6,500. Any service with short runs and frequent stops, particularly with loads between five and thirty cwt., is suitable for the battery vehicle. A large proportion of tradesmen's and similar services in towns and suburban districts comes within this category. The great advantages of the electric vehicle in lower running and maintenance costs are now augmented by the absence of restriction on the use of electric power for battery charging, in contrast with the present petrol restrictions.

The design of modern battery vehicles has been modelled closely on automobile practice. The weight of the battery necessitates a rather heavier frame, and special provision has to be made for accommodating the battery crates and for their easy inspection and removal. Four-wheel brakes are standard, and the drive to the back axle is by means of a propeller shaft with either a double-reduction bevel or worm gear. Pneumatic tyres of the medium pressure type have been found to give the best results by combining smooth running with economical power consumption. All the principal battery manufacturers now market special traction types able to withstand vibration and to provide heavy starting currents. Of the two principal types available, the lead-acid cell is most usually employed as its first cost is less than that of the alkaline battery. On the other hand, the latter has a life of about nine or ten years, whereas a lead-acid cell lasts only three or four, so that the difference in cost is levelled out. Owing to its higher internal resistance, the alkaline cell has a lower efficiency. For the small delivery van of the 12-15 ewt. class, the normal range of battery capacities is from 129 to 290 ampere hours. Capital costs are heavier than for an equivalent motor vehicle, but the life is approximately double, and both maintenance and running costs are considerably reduced.

\section{Indian Sculpture and Architecture}

THE Madras Government Museum has recently issued two publications, one of which is a guide to the archæological galleries of the Museum and is intended as an introduction to South Indian temple architecture and sculpture, while the second contains an illustrative series of photographic reproductions of examples of Indian sculpture, mostly southern, for use with the guide ("Guide to the Archæological Galleries". By Dr. F. H. Gravely and C. Sivaramamurti and other curators. Madras Government Press. Pp. $v+48+4$ plates. 8 annas. "Illustrations of Indian Sculpture, mostly Southern, for use with the Guide to the Archæological Galleries". By Dr. F. H. Gravely and C. Sivaramamurti. Pp. ii +xlv plates. Rs. 1.8). In the introductory remarks anticipating the text of the Guide, the principle is laid down that "The display of museum collections to the public aims at fostering a deep and intelligent interest in the universe of which we form a part, especially our immediate surroundings", and it is added that the arrangement and display of this section of the Museum's exhibits have been attempted in such a way as to help visitors "to recognize for thernselves the general affinities and probable period of temples and seulptures they see outside". With this praiseworthy objective, the authors sketch briefly the history of Indian art from the time of Asoka and in the centuries before our era down to the 'modern' period, with 
abundant references to the photographs and casts illustrating the Northern Schools, as well as to the actual exhibits from those of the South, special attention necessarily being directed to the Gupta period and Amaravarti.

No stronger plea than that afforded by these guides could be put forward for the adoption of a vigorous forward policy on the educational side throughout the museums of India. As the report of the Museums Commission showed, these institutions are already places of popular resort; but it depends upon the arrangement and administration of the museum itself whether they are mere repositories of 'curios', or really serve to bring home to the people the continuity in spiritual meaning underlying objects and buildings and structures familiar to them in their daily life. In the East, the function of the archæological museum is concerned with things of which the spirit, and sometimes, if not always, the form, is still alive.

\section{Instructional Films in India}

Mr. C. F. Strickxand has recently published a paper on "Instructional Films in India" (J. Roy. Soc. Arts). They supply a ready means of education in a country which "it is not possible to make literate in the next ten years", though during that period instruction concerning good government must be acquired. Adults have to be educated and already Bengal is credited with 1,000 cinemas and 500 touring companies. But most of the films shown are nonIndian and 45 per cent of them are American. They are predominantly unsuited to Indian ideas and modes of thought. Indians do not think continually "in terms of sex emotion or crime". Some educational films are now made in India and several are on loan, but these are meant chiefly for the juvenile population. Mr. Strickland explained the requirements and limitations of the Indian adult, one of which is a pace much less rapid than that to which we are accustomed. This speed with perpetual excitement is, we note, quite unnatural, lacking the tension and relaxation which prevail in life and in the best stories of action, such as the "Three Musketeers". It is, in fact, the consequent strain on the mind which makes these pictures so easily forgotten.

\section{Totaquina}

IN a recent paper (Asiatic Res., 35, 777 ; 1939), M. Ciuca states that in its search for an anti-malarial preparation cheaper than quinine but equally efficacious, the Malaria Commission of the League of Nations instituted research into the efficacy, compared with that of quinine, of a certain number of secondary alkaloid mixtures, such as kinetum, chineto, cinchona febrifuge, etc., used in the treatment of malaria in various countries. Research carried out in more than 4,000 patients in malarious countries proved that the efficacy of preparations containing 60-80 per cent crystallizable alkaloids including 15 per cent quinine was equal to that of quinine alone. The Commission has given the name of 'Totaquina' to a new preparation which is a mixture of cinchona bark alkaloids containing at least 75 per cent crystallizable alkaloids and not less than 15 per cent quinine. The advantage of the new preparation is a distinctly lower price, which is mainly due to the method of extraction, while its efficacy is equal to or only slightly less than that of quinine.

\section{Seeing at Night}

A. PAPER by R. G. Hopkinson, of the Research Laboratories, General Electric Co., Ltd., published in the Electrical Review of March 1, on "Seeing at Night", shows that valuable progress has been made on this important subject during the last few years, esperially in connexion with black-out conditions. Under weak illumination, the response of the eye is quite different from that under normal conditions. So far as light is gathered by the lens of the eye and is brought to a focus upon the retina, it functions like a camera, the retina acting like a photographic plate in recording the scene for the brain to interpret. The retina is provided, however, with two separate kinds of receptor nerve cells, the 'cones', which usually respond to bright scenes, and the 'rods', which respond to dark scenes. In daylight the cones only function. With bright artificial light both rods and cones are working, the rods recording the shadows and the cones recording the highlights for the brain. Under black-out conditions the rods alone are functioning.

Black-out vision is much inferior to day vision for the following reasons. (1) The rods do not record colours, hence black-out vision is devoid of colour sensation; all colours appear as varying grades of black and grey. (2) There are fewor rods per unit area of the retina than there are cones. The effect is analogous to that of a newspaper reproduction of a photograph, which is made up of a number of dots and is therefore less clear than the original. This handicap is the more serious since it is just that region of the retina which normally receives the clearest image, the fovea centralis, where the rods are fewest. Hence, as many must have noticed at low illuminations, vision is often better around the periphery of the eye.

\section{New Commercial Fruits in the United States}

O. Atkins writes in the American Fruit Grower (Dec. 1939) on the utility of the wild dryland blueberry (Vaccinium vaccillans $\mathrm{Kalm}$ ) in relation to soil conservation. Experiments have shown that it has unusual erosion-resistant qualities on account of its underground shoots, which send out a mass of fine roots and bind the soil together over a large area. In addition to this useful property, the blue-black fruits promise to form a successful commercial crop, and as the plant will grow and fruit in partial shade or full sunlight it is well suited to 'hill-culture'. A systematic breeding programme is being undertaken by the U.S. Department of Agriculture and Soil Conservation Service.

The papaya (Caprica papaya L.), according to S. J. Lynch, writing in the same journal, is now being grown commercially in South Florida. The texture of the flesh is similar to that of a 